\title{
A rapid automated screening technique for the detection of placental-like alkaline phosphatase in malignant disease
}

\author{
R. C. JENNINGS, D. BROCKLEHU RST, AND M. HIRST \\ From the Department of Pathology, General Hospital, Altrincham, Cheshire
}

SYNOPSIS An automated heat-stability procedure at $65^{\circ} \mathrm{C}$ for the detection of heat-stable placental and placental-like alkaline phosphatase is described. Placental-like enzymes were found in the serum of three patients suffering from malignant disease and one of these is described in detail.

Fishman, Inglis, Stolbach, and Krant (1968c) reported a man suffering from disseminated bronchogenic carcinoma whose serum contained a heat-stable alkaline phosphatase (APase) indistinguishable from APase of placental origin. At necropsy extracts of the primary tumour and metastases showed a high concentration of this variant enzyme which was not present in the tissue of origin and an ectopic production by the tumour cells was suggested. These workers (Stolbach, Krant, and Fishman, 1969) in a subsequent screening survey of 590 patients with various malignant conditions identified 27 whose serum contained placental-like enzymes.

In view of these findings it seemed that an automated screening test to detect and monitor such cases would be of value. The details of such an automated heat-stability test at $65^{\circ} \mathrm{C}$ are described. The relative sensitivity of this method in detecting placental-like APase is compared with starch gel electrophoresis with and without prior immunological precipitation.

\section{Materials and Methods}

AUTOMATED $65^{\circ} \mathrm{C}$ HEAT STABILITY PROCEDURE The manifold flow diagram (Fig. 1) demonstrates the method of simultaneous placental enzyme and blank determinations. The placental APase is measured under optimal conditions after incubation at $65^{\circ} \mathrm{C}$ for approximately 15 minutes. The blank determination is not incubated at $65^{\circ} \mathrm{C}$. The method is a modification of the Technicon N28 procedure, the method of Kind and King (1954) modified by Marsh, Fingerhut, and Kirsh (1959). The sample stream is split equally by means of a PT-2 and diluted in disReceived for publication 30 September 1971. tilled water to facilitate its flow through the $65^{\circ} \mathrm{C}$ heating bath. The sample line is then cooled in an ice bath and combined with double strength buffer at $p \mathrm{H} 10.7$ and $144 \mathrm{mM}$ substrate concentration giving optimal conditions for the measurement of the remaining placental APase activity, ie, $p \mathrm{H} \mathrm{10.7}$ and $72 \mathrm{mM}$ concentration (Fishman, Ghosh, Inglis, and Green, 1968a). The blank line sample is also prediluted in distilled water and combined with doublestrength buffer, $p \mathrm{H} 10 \cdot 7$, before incubation at $37^{\circ} \mathrm{C}$. The standards are run through the manifold without incubation at $65^{\circ} \mathrm{C}$ bypassing the heating bath on the test channel. The calculation of a placental unit is identical to the methods described in the Technicon manual N28. One placental unit/100 $\mathrm{ml}$ serum liberates $1 \mathrm{mg}$ of phenol from a $72 \mathrm{mM}$ substrate at pH 10.7 in 15 minutes at $37^{\circ} \mathrm{C}$.

STARCH-GEL ELECTROPHORESIS AND

SEPHADEX-GEL FILTRATION

These procedures were performed as described by Jennings, Brocklehurst, and Hirst (1970).

TISSUE EXTRACTION

This was carried out as described by Morton (1950) except that saline was used instead of water as the diluting medium. The tumour extract was concentrated by air drying and pure fractions containing placental-like bands A and B (Fishman and Ghosh, 1967) were obtained by Sephadex gel filtration and identified by starch gel electrophoresis.

ANTIBODY SCREENING PROCEDURE FOR PLACENTAL-LIKE APASE

This was performed on serum or tissue extracts which could be heat denatured at $65^{\circ} \mathrm{C}$ for five 


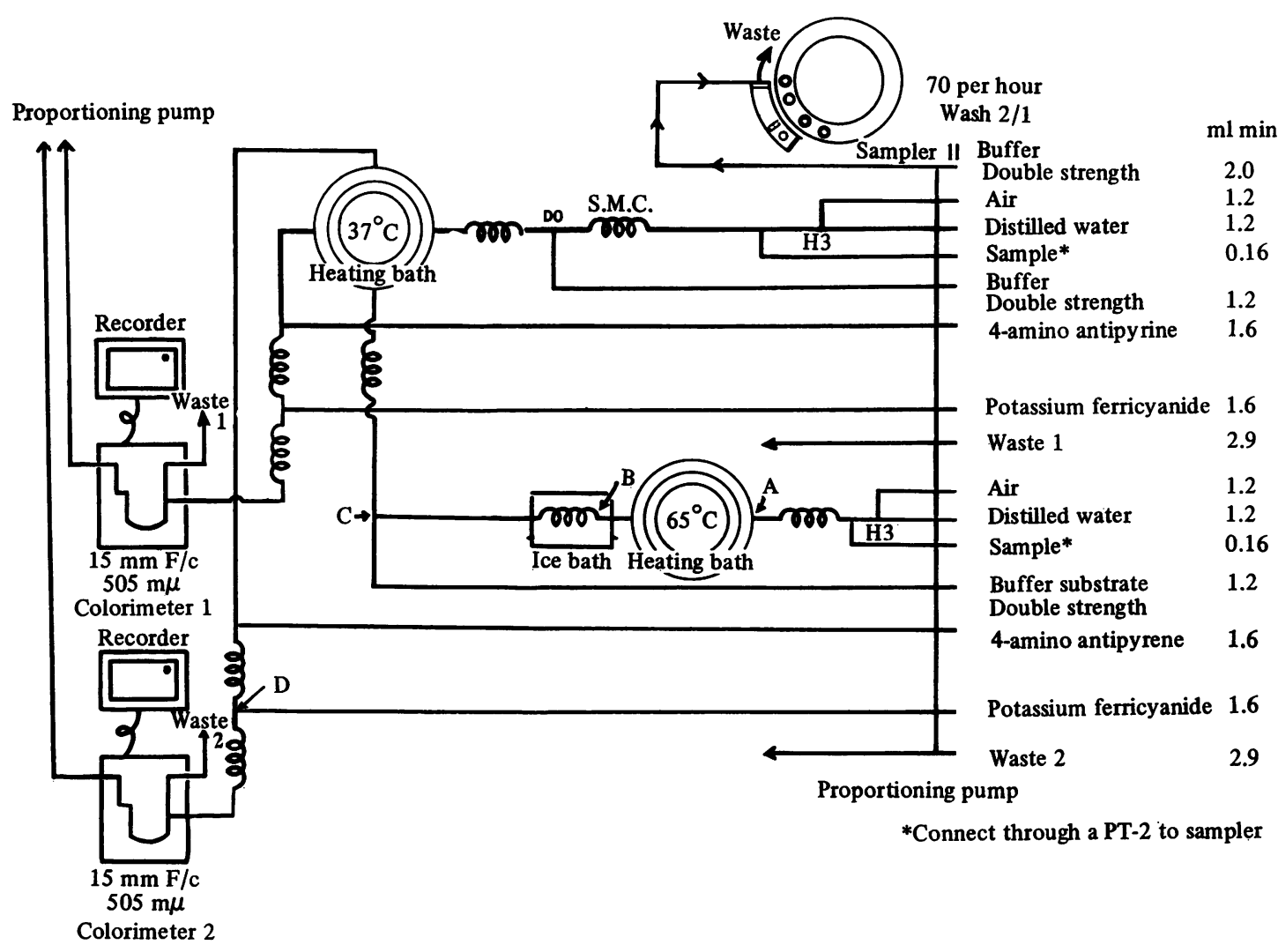

Fig. 1 Manifold flow diagram. Automated $65^{\circ} \mathrm{C}$ heat stability procedure.

$A$ and $B, C$ and $D$ are the timing points for the $65^{\circ} \mathrm{C}$ and $37^{\circ} \mathrm{C}$ incubations.

Single mixing coils. DO type T junctions are used throughout.

The reagents are as in the $\mathrm{N} 28$ method except that the buffer $\left.\left(\mathrm{Na}_{2} \mathrm{CO}_{3} \text { and } \mathrm{NaH} \mathrm{CO}\right)_{3}\right)$ concentrations are double the $\mathrm{pH}$ adjusted to 10.7 with $20 \% \mathrm{Na} \mathrm{OH}$. In the buffer substrate the $\mathrm{pH}$ is adjusted similarly and $144 \mathrm{mM}(36.6 \mathrm{~g} /$ litre $)$ disodium phenyl phosphate is added.

minutes if necessary. Antihuman placental rabbit antibody at a dilution of 1 in 500 in saline was mixed with equal volumes of antigen in the form of either serum or tissue extract and allowed to incubate at $37^{\circ} \mathrm{C}$ for 30 minutes and the antigen-antibody complex was then subjected to starch gel electrophoresis (Fishman, Inglis, Green, Antiss, Ghosh, Reif, Rustigian, Krant, and Stolbach, 1968b).

\section{Results}

One thousand five hundred unselected sera from hospital inpatients have been examined using the $65^{\circ} \mathrm{C}$ heat stability procedure during a period of six months. Heat-stable APase was detected in three patients suffering from malignancy and one of these (Fig. 2) in whom it was possible to make a full necropsy analysis is described.

\section{Case Report}

J.W.B., a man aged 65 years, was admitted to hospital on 14 September 1970 complaining of a dulio aching pain in the epigastrium for three to four weeks $\mathrm{N}$ On examination an enlarged, hard, irregular livee was palpable. A diagnosis of secondary carcinomis of the liver was made but no primary site could be्w established. He was not jaundiced but his total serumo APase was $46 \mathrm{KA}$ units $/ 100 \mathrm{ml}$ consisting of $5 . \frac{\mathrm{t}}{6}$ placental units $/ 100 \mathrm{ml}$. This level rose to $67 \mathrm{KA}$ units $/ 100 \mathrm{ml}$ on 22 September with 8.3 placental? units. He became jaundiced early in October and this progressed steadily until his death on 11 November $\overline{0}$ His serum APase two days before death was $167 \mathrm{KA} \overrightarrow{\mathrm{Q}}$ units $/ 100 \mathrm{ml}$ containing 33 placental units. Aț necropsy a large tumour mass was present at the hilum of the liver with separate satellite deposits in 


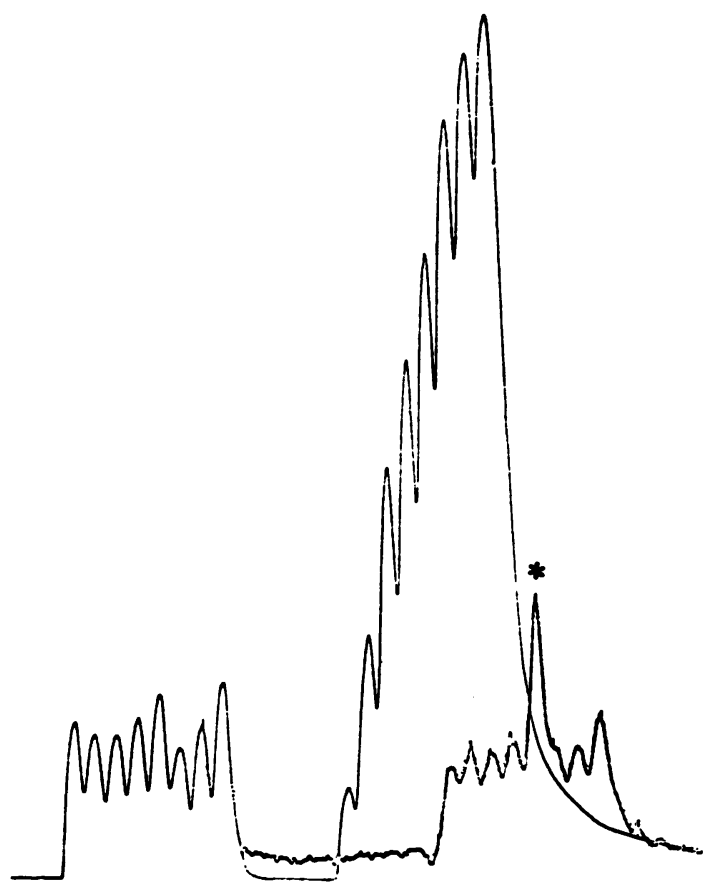

Fig. 2 AutoAnalyzer trace of the automated heatstability procedure showing from left to right blanks and standards, followed by tests with a heat-stable peak of activity (*).

the peripheral parts of the liver. The gall bladder could not be identified, being replaced by tumour tissue. Histologically the tumour was a mucussecreting rather anaplastic adenocarcinoma which was presumed to have originated from the hepatobiliary system. The entire liver was removed and stored at minus $20^{\circ} \mathrm{C}$.

Confirmatory evidence of the placental-like nature of the enzyme in serum and tumour extracts was demonstrated on starch gel electrophoresis after manual heat denaturation at $65^{\circ} \mathrm{C}$ for 30 minutes (Fig. 3). The bands of activity in the serum and tumour extracts were diffuse in nature and ran slightly behind placental controls. Tumour extracts of the enzyme showed a L-phenylalanine sensitivity similar to that of placental and intestinal enzymes. Manual heat denaturation curves at $65^{\circ} \mathrm{C}$ up to 30 minutes were similar to placental (Fig. 4) and gave better correlation after purification of the enzyme by Sephadex gel filtration. Antihuman placental rabbit antibody at a dilution of 1 in 1000 precipitated the tumour and serum enzyme antigens and also that of placental antigen preventing migration into starch gel on subsequent starch gel electrophoresis. This antibody crossreacted with intestinal

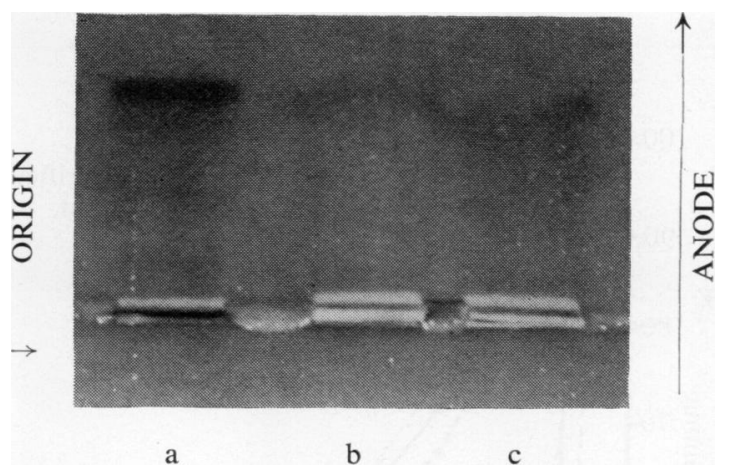

Fig. 3 Starch gel electrophoresis.

a Patient's native serum showing prominent front moving band of liver type partially obscuring placentaltype activity.

b Pregnancy serum heat denatured. Placental band still present.

c Patient's serum heat denatured. Residual diffuse activity of placental type.

extract at a dilution of 1 in 150 , a finding similar to that described by Fishman et al (1968b). This technique was not found to increase the limits of detection of placental-like APase in comparison with the $65^{\circ} \mathrm{C}$ heat stability procedure or starch gel electrophoresis of the enzyme after manual heat denaturation. A rabbit antibody raised to the patient's tumour showed similar specificity to placental and tumour extracts as did antihuman placental rabbit antibody.

Comparing the N28 method and the heat stability procedure described, it was apparent that the enzymes from this patient, both in serum and tumour extracts, showed certain different characteristics to that of placental enzyme obtained from pregnancy serum and placental extracts. A comparison of the N28 procedure with the described manifold (in which the enzyme is prediluted in water) resulted in an activation effect of 1.09 for placental extract compared with 0.94 for the tumour extract when $\mathrm{N} 28$ substrate and buffer conditions $(7.8 \mathrm{mM}$ and $p \mathrm{H}$ $10 \cdot 0)$ were used. Using the optimal conditions for

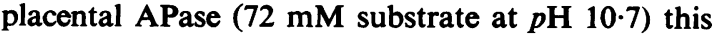
method showed an activation factor of 1.84 (SD 0.03) for pregnancy sera and 1.51 for the patient's sera compared with $\mathrm{N} 28$ substrate and $p \mathrm{H}$ conditions. In addition, predilution of serum in saline before sampling showed an activation factor of 1.38 in pregnancy serum but a reduction of activity in the patient's serum (factor $\mathbf{0 . 7 1}$ ). 


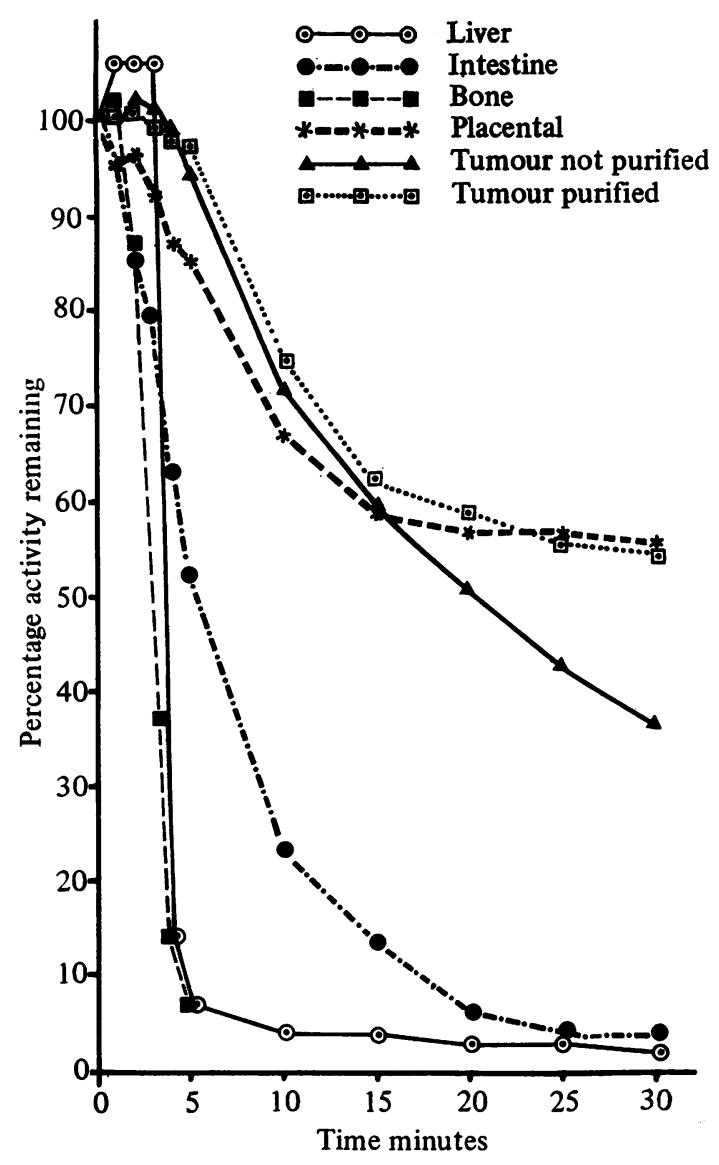

Fig. 4 Manual heat denaturation curves at $65^{\circ} \mathrm{C}$. Only the tumour extract has been purified by Sephadex gel filtration. Liver, bone, intestinal, and unpurified tumour are ordinary butanol extracts. APase activity measured by $\mathrm{N} 28$ method. No rigid control of $\mathrm{pH}$ was maintained.

\section{Discussion}

Heat denaturation at $55^{\circ} \mathrm{C}$ upon human tissue extracts containing APase was first described by Moss and King (1962). They noted differing heat stabilities for liver, bone, intestine, and kidney extracts. These observations were subsequently used by other workers to assess the relative amount of tissue-specific enzymes in serum (Posen, Neale, and Clubb, 1965; FitzGerald, Fennelly, and McGeeney, 1969). It was found that at $55^{\circ}$ and $56^{\circ} \mathrm{C}$ hepatic and osseous forms could be distinguished because of the greater sensitivity to heat inactivation of the latter type. At the higher temperature of $65^{\circ} \mathrm{C}$, however, hepatic, osseous, and intestinal forms are all almost completely inactivated within 15 minutes. Any residual activity under these conditions indicates the presence of placental or placental-like APase.

The automated method described for the detection and estimation of heat-stable serum APase at $65^{\circ} \mathrm{C}$ was developed from a $56^{\circ} \mathrm{C}$ procedure in use for the correlation of heat stability results and starch gel electrophoresis patterns in normal and pathological conditions. Many earlier procedures at $56^{\circ} \mathrm{C}$ have been semi-automated. The kinetic technique of $s$ Posen, Neale, Brudenell-Woods, and Birkett (1967), $\vec{\circ}$ a modification of which was used by Small (1969), $\overrightarrow{\vec{\omega}}$ was fully automated but this technique did not seem $\bar{\sigma}$ readily adaptable to routine use. The present method $\vec{\circ}$ at $65^{\circ} \mathrm{C}$ can, however, be easily used as a screening procedure in a routine clinical laboratory. This of method has been designed to detect and estimate placental APase, and the optimum conditions $\frac{\vec{b}}{0}$ required for this may not be exactly the same as those for placental-like enzymes found in malignancy. The activation effect of placental APase by pre- $\rightarrow$ dilution with water and the use of optimum $p H$ and substrate concentrations are factors which help in its detection by this method. In this connexion, $\vec{N}$ Cornish, Nale, and Posen (1970) noted an apparent $N$ increase in heat stability of APase with increasing aqueous dilution of serum until a peak was reached at a dilution of $1 / 250$.

In pregnancy the level of heat-stable placental APase may be used as a test of placental function and $\stackrel{\varnothing}{\varnothing}$ a possible method of predicting intrauterine foetal $\overrightarrow{\overrightarrow{\vec{P}}}$ death (Curzen and Morris, 1968). In the absence of $\frac{\circ}{3}$ pregnancy heat-stable serum APase appears to be present only in malignancy, usually of advanced type (Stolbach et al, 1969). These authors did not find any instances of its presence in non-malignant $\frac{?}{0}$ conditions nor have we in our series. Confirmatory $\frac{5}{3}$ evidence of the presence of placental-like APase in malignancy is best done by manual heat denatura- $\delta$ tion followed by starch gel electrophoresis. The ease of detection upon starch gel electrophoresis is 음 facilitated by previous heat inactivation of other $D$ APases at $65^{\circ} \mathrm{C}$ (Fig. 3) as the other bands present may mask the placental-like activity. This probably explains why other authors reviewing starch gel ${ }^{\circ}$ electrophoresis or polyacrilamide findings in clinical ${ }^{N}$ disease states have not described any such cases ${ }_{\omega}^{N}$ (Newton, 1967: Canapa-Anson and Rowe, 1970). In the present case the abnormal enzyme in the serumco showed a diffuse band on starch gel electrophoresis $\overline{\mathbb{}}$ running slightly behind the placental position but $\stackrel{\odot}{?}$ with some trailing towards the origin. Its diffuse 7 nature suggested a heterogeneous composition, possibly analogous to the polymorphic nature of APase of placental origin (Robson and Harris, 1965). $\stackrel{\otimes}{\stackrel{\otimes}{\circ}}$ The same enzyme showed a similar diffuse band 
pattern upon polyacrilamide gel electrophoresis (Jacoby and Bagshawe, 1971). The tumour extract showed an additional B band on starch gel electrophoresis analogous to the $B$ band described in pregnancy (Fishman and Ghosh, 1967). The enzyme present in this patient conformed in four major characteristics to placental APase. It was heat resistant at $65^{\circ} \mathrm{C}$, L-phenylalanine sensitive, and electrophoretically and immunologically similar. It did, however, show some different features. It was activated in serum by a factor of 1.51 by optimal $p \mathrm{H}$ and substrate conditions compared with a factor of 1.84 in pregnancy sera, and predilution in saline did not show the activation effect found in pregnancy serum. Chemical inhibitory studies using EDTA and L-leucine (Jacoby and Bagshawe, 1971) also showed differences from placental APase. Nakayama, Yoshida, and Kitamura (1970) showed similar L-leucine findings in a case of pleuritic carcinomata with heat-stable APase in the serum. These minor chemical variations may not invalidate Fishman's suggestion that this form of tumour enzyme ectopia results from derepression of the genome, and further detailed chemical studies may reveal a whole spectrum of ectopic placental-like enzymes.

The availability of a simple automated procedure will make the detection of these enzyme variants easier and provide more information regarding the frequency of their occurrence and level of activity during the course of malignant disease.

We wish to thank Dr C. D. R. Pengelly for permission to publish details of this case, $\mathrm{Dr} H$. Allison for the necropsy report, Dr C. Wilde for his helpful advice, Mr J. W. Firth for the illustrations, and Mrs L. J. Blair for typing the manuscript. Mr B. Jacoby of Charing Cross (Fulham) Hospital kindly provided us with antihuman placental rabbit antibody, and Dr J. O'H. Tobin helped in raising the antitumour rabbit antibody.

We are indebted to Mrs S. Worthington and the Manchester Regional Hospital Board for financial assistance.

\section{References}

Canapa-Anson, R., and Rowe, D. J. F. (1970). Electrophoretic separation of tissue-specific serum alkaline phosphatases. J. clin. Path., 23, 499-508.

Cornish, C. J., Neale, F. C., and Posen, S. (1970). An automated fluorometric alkaline phosphatase microassay with 4-methylumbelliferyl phosphate as a substrate. Amer. J. clin. Path., 53, 68-76.

Curzen, P., and Morris, R. N. (1968). Heat stable alkaline phosphatase in maternal serum. J. Obstet. Gynaec. Brit. Cwlth, 75, 151-157.

Fishman, W. H., and Ghosh, N. K. (1967). Isoenzymes of human alkaline phosphatase. Advanc, clin. Chem., 10, 255-370.

Fishman, W. H., Ghosh, N. K., Inglis, N. I., and Green, S. (1968a). Quantitation of placental isoenzyme of alkaline phosphatase in pregnancy sera. Enzymologia, 34, 317-320.

Fishman, W. H., Inglis, N. I., Green, S., Antiss, C. L., Ghosh, N. K., Reif, A. E., Rustigian, R., Krant, M. J., and Stolbach, L. L. (1968b). Immunology and biochemistry of Regan isoenzyme of alkaline phosphatase in human cancer. Nature (Lond.), 219, 697-699.

Fishman, W. H., Inglis, N. R., Stolbach, L. L., and Krant, M. J. (1968c). A serum alkaline phosphatase isoenzyme of human neoplastic cell origin. Cancer Res., 28, 150-154.

Fitzgerald, M. X. M., Fennelly, J. J., and McGeeney, K. (1969). The value of differential alkaline phosphatase thermostability in clinical diagnosis. Amer. J. clin. Path., 51, 194-201.

Jacoby, B., and Bagshawe, K. D. (1971). Placental-type alkaline phosphatase from human tumour tissue. Clin. chim. Acta, 35 , 473-481.

Jennings, R. C., Brocklehurst, D., and Hirst, M. (1970). A comparative study of alkaline phosphatase enzymes using starch-gel electrophoresis and sephadex gel-filtration with special reference to high molecular weight enzymes. Clin. chim. Acta, 30, 509-517.

Kind, P. R. N., and King, E. J. (1954). Estimation of plasma phosphatase by determination of hydrolysed phenol with aminoantipyrine. J. clin. Path., 7, 322-326.

Marsh, W. H., Fingerhut, B., and Kirsh, E. (1959). Adaptation of an alkaline phosphatase method for automatic colorimetric analysis. Clin. Chem., 5, 119-126.

Morton, R. K. (1950). Separation and purification of enzymes associated with insoluble particles. Nature (Lond.), 166, 1092-1095.

Moss, D. W., and King, E. J. (1962). Properties of alkaline phosphatase fractions separated by starch-gel electrophoresis. Biochem. J., 84, 192-195.

Nakayama, T., Yoshida, M., and Kitamura, M. (1970). L-leucine sensitive, heat stable, alkaline-phosphatase isoenzyme detected in a patient with pleuritis carcinomatosa. Clin. chim. Acta, 30, 546-548.

Newton, M. A. (1967). The clinical application of alkaline phosphatase electrophoresis. Quart.J. Med., 36, 17-28.

Posen, S., Neale, F. C., Brudenell-Woods, J., and Birkett, D. J. (1966). Continuous determination of enzyme activity during heat inactivation. (Letter to the Editor.) Lancet, 1, 264-265.

Posen, S., Neale, F. C., and Clubb, J. S. (1965). Heat inactivation in a study of human alkaline phosphatases. Ann. intern. Med., 62 , 1234-1243.

Robson, E. B., and Harris, H. (1965). Genetics of the alkaline phosphatase polymorphism of the human placenta. Nature (Lond.), 207, 1257-1259.

Small, C. W. (1969). A study of heat inactivation of serum alkaline phosphatases by an automated technique. Clin. chim. Acta, 23, 347-352.

Stolbach, L. L., Krant, M. J., and Fishman, W. H. (1969). Ectopic production of an alkaline phosphatase isoenzyme in patients with cancer. New Engl. J. Med., 281, 757-762. 